\title{
THE EFFECT OF MATERNAL AGE ON OVULATION, CORPORA LUTEA OF PREGNANCY, AND IMPLANTATION FAILURE IN MICE
}

\author{
S. M. HARMAN AND G. B. TALBERT \\ Department of Anatomy, Downstate Medical Center, State University of New York, \\ Brooklyn, New York
}

(Received 25th August 1969)

\begin{abstract}
Summary. C57Bl female mice aged 4 to 7 months (controls) and 8 to 9 , 10 to 11,12 to 13 , and 14 to 15 months were mated and killed at $12 \mathrm{hr}$, $60 \mathrm{hr}$ or $7 \frac{1}{2}$ days post coitum (p.c.). Corpora lutea were counted and evaluated in serially sectioned ovaries. Implantation sites were counted in the animals killed $7 \frac{1}{2}$ days p.c. The mean number of implantations in 10- to 11-month-old mice was less than in the control animals. This decrease was closely associated with morphological degeneration of corpora lutea of pregnancy. By 12 to 13 months of age most animals had neither implantation sites nor recognizable corpora lutea of pregnancy $7 \frac{1}{2}$ days after mating. These two changes were highly correlated and were not due to a decrease in the number of ovulations as determined by examination of the ovaries of animals killed 12 or $60 \mathrm{hr}$ p.c.

It was concluded that the initial decline in fertility with increased maternal age in this strain of mouse may be due to failure of luteal support of the uterus.
\end{abstract}

\section{INTRODUCTION}

A decline in reproductive capacity with increasing age has been demonstrated in polytocous animals such as rats (Asdell, Bogart \& Sperling, 1941), hamsters (Soderwall, Kent, Turbyfill \& Britenbaker, 1960) and mice (Thung, Boot \& Muhlbock, 1956). The age at which the litter size and frequency of pregnancy decline, varies in different strains of mice (Thung et al., 1956). The onset of relative infertility in old mice precedes termination of oestrous cycles (Jones \& Krohn, 1959; Biggers, Finn \& McLaren, 1962b), and occurs in most strains which have been studied while the ovary still has many primary oocytes and developing follicles (Jones \& Krohn, 1961).

Counts of developing corpora lutea (CL) also indicate that there is no decrease in ovulation rate at the onset of senile infertility (Hollander \& Strong, 1950; Biggers et al., 1962b).

Implantation of fertilized ova transferred from the uteri of young adult female mice into uteri of old host mice was less successful than similar ova placed into uteri of young host mice (Talbert \& Krohn, 1966). In the same study, ova obtained from young and old mice survived equally well in the uteri 
of young host animals. These results suggest that deficiency of the uterine environment, rather than defective ova, was responsible for the decline in reproductive capacity in ageing female mice. Whether this deficiency was due to some defect in the endocrine support of the uterus or to an intrinsic age change in the uterus, as suggested by the work of Finn (1966), was not established.

The present study was designed to investigate whether the initial onset of senile decline in reproductive function in a single inbred strain of mouse could be related to ageing changes in ovarian morphology, and hence whether the deficient uterine environment in ageing mice suggested by Finn (1963) and by Talbert \& Krohn (1966) might be secondary to ovarian failure.

\section{MATERIALS AND METHODS}

The C57Bl/6J mice were obtained from Jackson Memorial Laboratory in Bar Harbor, Maine, U.S.A. The old animals were retired breeders which had delivered at least three litters before shipment. Young adult females were obtained from the same source when they were about 7 weeks of age and delivered one litter in our laboratory before being used in this study.

Female mice of the ages shown in Table 1 were mated with young adult $\mathrm{AJ}$ males. Animals which were to be killed 12 or $60 \mathrm{hr}$ after mating were placed

TABLE 1

EFFEGT OF MATERNAL AGE ON NUMBER OF IMPLANTATION SITES IN MICE EXAMINED ON 8TH DAY OF GESTATION

\begin{tabular}{c|c|cc|c}
\hline $\begin{array}{c}\text { Age } \\
\text { (months) }\end{array}$ & $\begin{array}{c}\text { Total } \\
\text { females }\end{array}$ & \multicolumn{2}{|c|}{$\begin{array}{c}\text { Animals with implants } \\
\text { No. }\end{array}$} & $\begin{array}{c}\text { Implants/mouse } \\
\text { (mean } \pm \text { S.E.) }\end{array}$ \\
\hline 4 to 7 & 30 & 22 & $73 \cdot 3$ & $6 \cdot 86 \pm 0 \cdot 80$ \\
8 to 9 & 33 & 23 & $69 \cdot 7$ & $5 \cdot 97 \pm 0 \cdot 73$ \\
10 to 11 & 31 & 23 & $74 \cdot 2$ & $4 \cdot 45 \pm 0 \cdot 62^{* *}$ \\
12 to 13 & 29 & $8^{*}$ & $27 \cdot 6$ & $1 \cdot 21 \pm 0 \cdot 40^{* * *}$ \\
14 to 15 & 31 & $4^{*}$ & 12.9 & $0.61 \pm 0 \cdot 30^{* * *}$ \\
\hline
\end{tabular}

* Chi-square test indicates distribution different from 4- to 7-month-old group, $P<0 \cdot 001$. $P<0.02$.

* Mean differs significantly from 4- to 7-month-old group,

$* * *$ Mean differs significantly from 4- to 7-month-old group, $P<0.001$.

with males at 22.00 hours and examined for vaginal plugs at midnight and again at 02.00 hours, at which time males and females were separated. Mice which had mated were killed at 11.00 hours or 13.00 hours of the following day $(12 \mathrm{hr})$ or the $3 \mathrm{rd}$ day $(60 \mathrm{hr})$ after mating. Animals which were to be killed $7 \frac{1}{2}$ days after mating were placed with males in the evening and examined for vaginal plugs before 10.00 hours the following morning. These animals were killed on the afternoon of the 8th day after mating.

Animals were killed by cervical dislocation. The ovaries of the animals in the 12- and 60-hr groups were fixed in Bouin's solution, serially sectioned at $10 \mu$, and stained with haematoxylin and eosin. Counts were made of the number of 
follicles which ovulated during the cycle when mating occurred and developing CL were noted.

The number of implantation sites was counted in each uterine horn of the animals killed $7 \frac{1}{2}$ days after mating. The ovaries were prepared for histological study as described above and the number of corpora lutea of pregnancy (CLP) was determined.

The condition of CLP was evaluated by the following criteria: functional CLP are distinguished from non-functional cyclic CL by their greater size; homogeneity of staining; greater cytoplasmic : nuclear ratio; clearly visible cell boundaries; better developed radially-arranged vascular network; and a cytoplasm containing finely distributed fat which, with haematoxylin and eosin staining, gives the luteal cells a slightly granular appearance.

Involution of CLP can also be recognized. Signs of degeneration are coarse vacuolation of cytoplasm of the luteal cells and cellular swelling indicative of lipid accumulation. Some cells show darker staining of the cytoplasm, shrinkage of nuclei, and loss of clear cell boundaries. There is also a reduction in the sinusoidal capillary network and infiltration of some cLP by leucocytes.

All slides were studied without knowledge of the number of implantation sites or of the age of the animal from which the ovaries had been obtained. This was done to eliminate bias in evaluation of the CLP.

\section{RESULTS}

Table 1 shows that the mean number of implantation sites per animal had declined significantly by 10 to 11 months of age and decreased further to a mean of less than one implantation site per animal by 14 to 15 months of age.

TABLE 2

EFFECT OF MATERNAL AGE ON NUMBER OF GLP ON THE 8TH DAY OF GESTATION

\begin{tabular}{c|c|cc|c}
\hline $\begin{array}{c}\text { Age } \\
\text { (months) }\end{array}$ & $\begin{array}{c}\text { Total } \\
\text { females }\end{array}$ & \multicolumn{2}{|c|}{$\begin{array}{c}\text { Animals with CLP } \\
\text { No. }\end{array}$} & $\begin{array}{c}\text { CLP/mouse for mice } \\
\text { with one or more CLP } \\
\text { (mean } \pm \text { S.E.) }\end{array}$ \\
\hline 4 to 7 & 30 & 26 & 86.7 & $10 \cdot 2 \pm 1 \cdot 67$ \\
8 to 9 & $31 \dagger$ & 25 & 80.7 & $9 \cdot 8 \pm 0.45$ \\
10 to 11 & 31 & 27 & 86.7 & $9 \cdot 8 \pm 0.68$ \\
12 to 13 & 29 & $11^{*}$ & 37.9 & $7 \cdot 9 \pm 0.82$ \\
14 to 15 & 31 & $7^{*}$ & $22 \cdot 6$ & $9 \cdot 0 \pm 0.69$ \\
\hline
\end{tabular}

* Chi-square test indicates distribution differs significantly from 4- to 7 -month-old group, $P<0.001$.

$\dagger$ Two animals included in Table 1 are not included here due to loss of ovaries in processing.

At 10 to 11 months of age, there was no decrease in the percentage of animals which had at least one implantation site. By 12 to 13 months of age, however, there was a highly significant decrease in the percentage of pregnant animals.

The data in Table 2 show that the number of animals which had recognizable GLP $7 \frac{1}{2}$ days after mating decreased significantly beginning at 12 to 13 
months of age. However, the mean number of CLP per mouse in animals which had at least one CLP did not decrease with age.

Implantation sites were never seen in animals lacking recognizable CLP, and complete failure of implantation was relatively rare in animals which had

TABLE 3

EFFECT OF MATERNAL AGE ON OVULATION IN MICE STUDIED AT

12 AND 60 HR AFTER MATING

\begin{tabular}{c|c|c|cc|c}
\hline $\begin{array}{c}\text { Age } \\
\text { (months) }\end{array}$ & $\begin{array}{c}\text { Time since } \\
\text { mating }(\text { hr })\end{array}$ & $\begin{array}{c}\text { Total } \\
\text { females }\end{array}$ & \multicolumn{2}{|c|}{$\begin{array}{c}\text { Animals ovulating } \\
\text { No. }\end{array}$} & $\begin{array}{c}\text { Ovulations/mouse } \\
\text { (means } \pm \text { S.E.) }\end{array}$ \\
\hline 4 to 7 & 12 & 10 & 10 & $100 \cdot 0$ & $9 \cdot 4 \pm 0.37$ \\
& 60 & 10 & 8 & $80 \cdot 0$ & $10 \cdot 2 \pm 0.54$ \\
10 to 11 & 12 & 13 & 10 & 76.9 & $10.2 \pm 0.66$ \\
& 60 & 13 & 9 & $69 \cdot 3$ & $10 \cdot 7 \pm 0.87$ \\
12 to 13 & 12 & 14 & 13 & $92 \cdot 8$ & $8 \cdot 5 \pm 0.84$ \\
& 60 & 14 & 10 & 76.9 & $8.9 \pm 0.55$ \\
\hline
\end{tabular}

TABLE 4

EFFECT OF MATERNAL AGE ON MORPHOLOGY OF CLP ON THE 8TH DAY OF GESTATION

\begin{tabular}{|c|c|c|c|c|c|c|}
\hline \multirow{2}{*}{$\underset{\text { (months) }}{\text { Age }}$} & \multirow{2}{*}{$\begin{array}{c}\text { Total } \\
\text { females }\end{array}$} & \multicolumn{2}{|c|}{$\begin{array}{l}\text { Animals with } \\
\text { no } C L P\end{array}$} & \multirow{2}{*}{$\begin{array}{c}\text { No. of animals } \\
\text { with recognizable } \\
\text { CLP }\end{array}$} & \multicolumn{2}{|c|}{$\begin{array}{c}\text { Animals with } \\
\text { degenerate } C L P\end{array}$} \\
\hline & & & $\%$ & & No. & $\%$ \\
\hline $\begin{array}{c}4 \text { to } 7 \\
8 \text { to } 9 \\
10 \text { to } 11 \\
12 \text { to } 13 \\
14 \text { to } 15\end{array}$ & $\begin{array}{l}30 \\
31 \\
31 \\
29 \\
31\end{array}$ & $\begin{array}{c}4 \\
6 \\
4 \\
18^{*} \\
24^{*}\end{array}$ & $\begin{array}{l}13 \cdot 3 \\
19 \cdot 3 \\
12 \cdot 9 \\
62 \cdot 1 \\
77 \cdot 4\end{array}$ & $\begin{array}{r}26 \\
25 \\
27 \\
11 \\
7\end{array}$ & $\begin{array}{c}5 \\
5 \\
17^{*} \\
7 * \\
4\end{array}$ & $\begin{array}{l}19 \cdot 2 \\
20 \cdot 0 \\
63 \cdot 0 \\
63 \cdot 6 \\
57 \cdot 1\end{array}$ \\
\hline
\end{tabular}

* Chi-square test shows distribution differs significantly from 4- to 7-month-old group, $P<0.008$.

recognizable CLP. This is clearly shown in the 12- to 13-month-old group, in which only three of the twenty-one animals which had no implantation sites had recognizable cLP (compare Tables 1 and 2).

Table 3 indicates that the mean number of ovulations per mouse had not decreased in mice of 12 to 13 months of age. There was also no evidence that the CLP were failing to develop normally $60 \mathrm{hr}$ after mating in the oldest animals studied.

In the present study, the morphology of CLP in many animals conformed to the above description of functional GL (Pl. 1, Fig. 1). There were, however, a number of animals whose ovaries contained degenerating CLP (Pl. 1, Fig. 2). When an animal had cLP which were degenerate, this change was found in all the CLP of that animal.

\section{EXPLANATION OF PLATE 1}

FIG. 1. Normal $7 \frac{1}{2}$-day p.c. CLP showing homogeneity of luteal cell cytoplasm, large sinusoidal vascular spaces (arrows) and typical vesicular nuclei. $\times 400$.

FIG. 2. Degenerating $7 \frac{1}{2}$-day p.c. CLP showing area of clear vacuolated cells (A), area of dark staining cells $(\mathbf{B})$, narrow vascular channel (arrow), and presence of deformed and pycnotic nuclei. $\times 400$. 
PLATE ]

1700

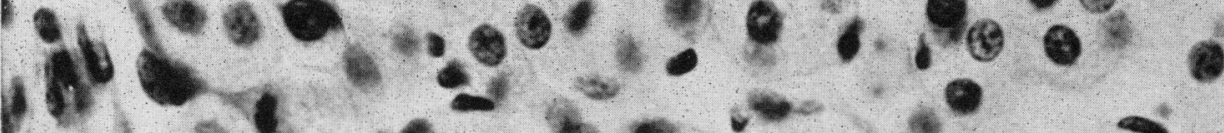
(4ílo

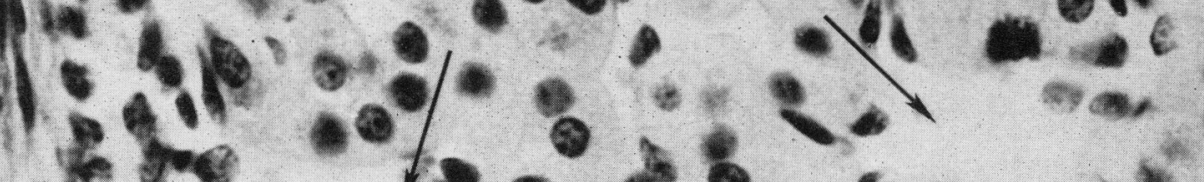

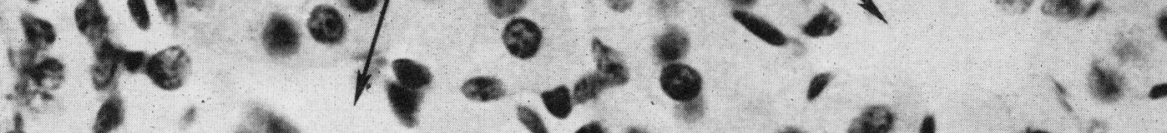
$1: 0100.10$

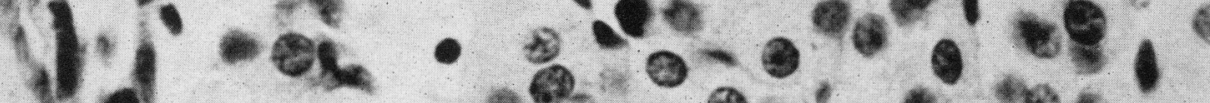
$01 \div-\div ; 0 ;$ al 1 -

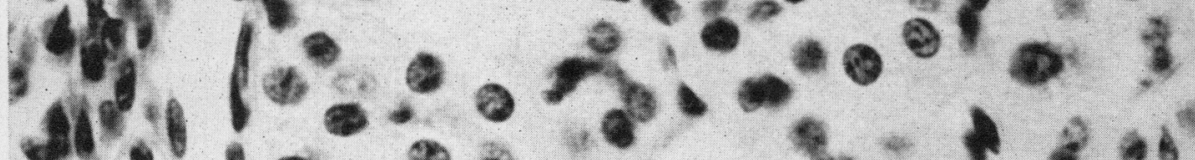
11. 10:- - $3+1800^{\circ}$

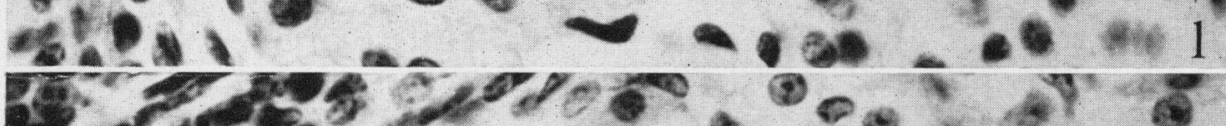

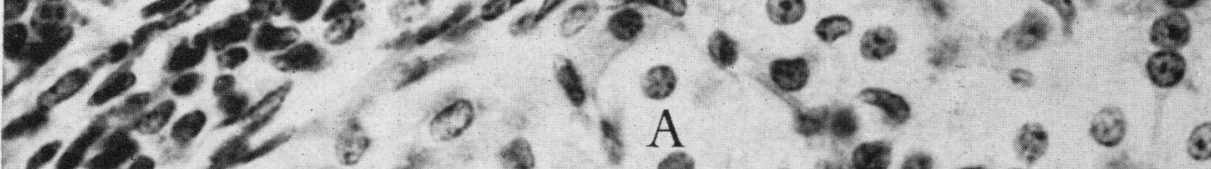

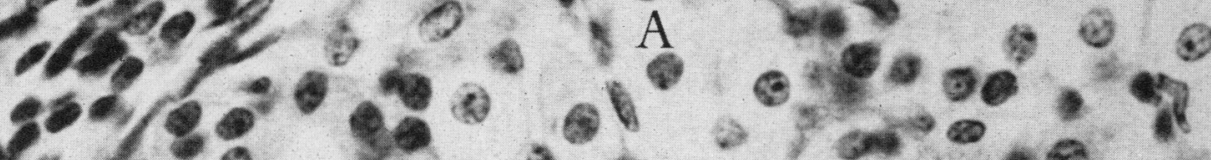
Tp a

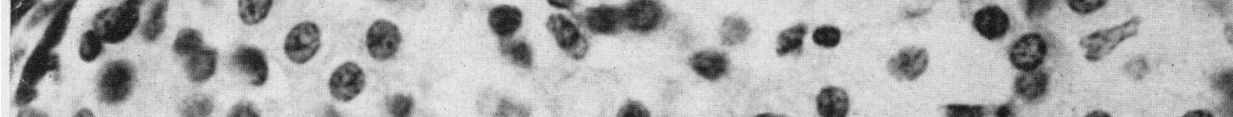

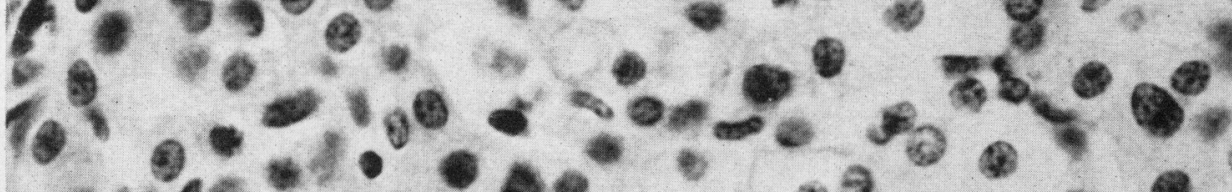

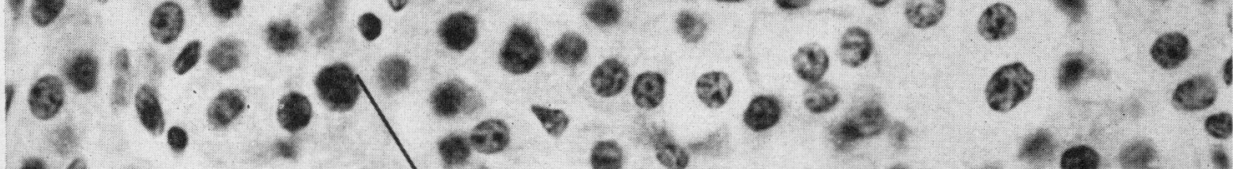
- 0 o $\because:-1$. \%.: 340.93 coot of: 
Table 4 shows the effect of maternal age on the percentage of animals with degenerate CLP. There was a significant increase in the percentage of such animals at 10 to 11 months and at 12 to 13 months of age. Although the 14- to 15-month-old groups also showed a very high percentage of animals with degenerate CLP, the number of animals at this age with any CLP was very small. Table 4 also shows that, with advancing maternal age, there was first an increase in the proportion of mice which had ovaries with degenerate CLP, and then in the percentage of mice with no GLP.

The implantation rate in animals with degenerate GLP was significantly lower than that of animals of the same age with normal CLP in every group except the 14- to 15-month-old mice (Text-fig. 1). There was, however, some

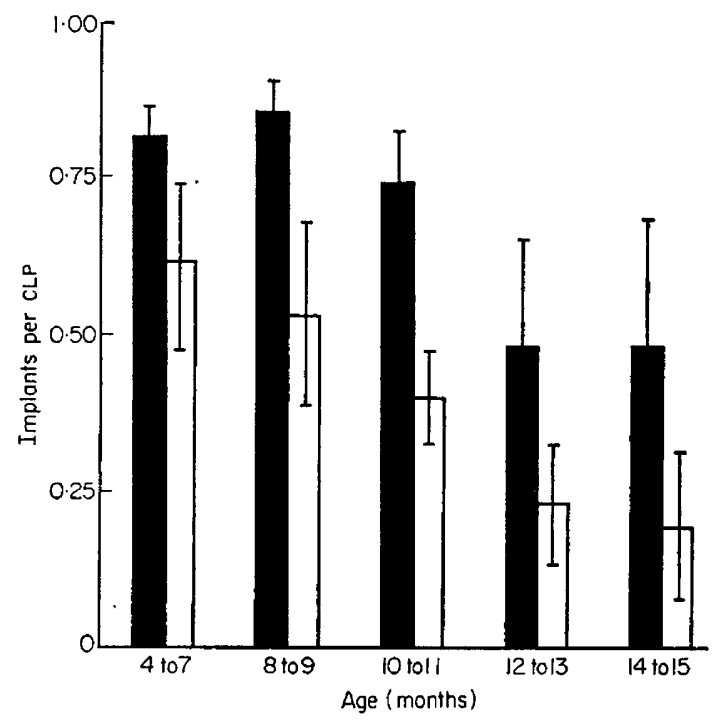

TEXT-FIG. 1. Effect of increasing maternal age and morphology of CLP on the mean number of implants per ovulation, shown with the $95 \%$ confidence limits. Solid columns, animals with normal CLP; open columns, animals with degenerating CLP.

indication of a decrease in implantation rate in 12- to 15-month-old females with apparently normal CLP.

\section{DISCUSSION}

In this study, the earliest significant decline in fertility was demonstrated in mice which were 10 to 11 months of age. At this age, there was a decrease in the mean number of implants per animal but no decrease in the number of animals with at least one implant. By 12 to 13 months of age, the majority of animals failed to achieve implantation. These data agree with previous descriptions of decline in reproductive function in which decline in litter size preceded total loss of reproductive capacity (Thung et al., 1956; Jones \& Krohn, 1961).

The finding of an increasing number of aged animals with no recognizable CLP has not been reported previously. This phenomenon was seen first in the 12- to 13-month-old mice, which was also the age at which the first increase in the number of animals with no implantation sites occurred. These two 
events were highly correlated as shown above. Since animals killed up to $60 \mathrm{hr}$ after mating showed no decrease in the number of developing CL per animal of 12 to 13 months of age, it appears that absence of CLP on the 8th day of gestation was due to failure of functional cLP to develop after ovulation. Previous investigators have also found no decrease in ovulation rate at the time of onset of senile infertility in mice (Hollander \& Strong, 1950; Biggers et al., 1962b).

The changes found in the CLP which were observed in the present study appear to be similar to those reported by Deanesly (1930) and Bassett (1943) in involuting CL. Loeb (1948) noted the appearance of vacuolation of lutein cells as an indication of degeneration of CL. Similar changes were observed by Biggers, Finn \& McLaren (1962a) in the ovaries of 53- to 93-week-old mice. However, in none of these studies were the degenerative changes associated with a decline in the rate of implantation. The percentage of animals with apparent degenerative changes in CLP greatly increased by 10 to 11 months of age, and was associated with a reduction in the efficiency of implantation. Since the implantation efficiency of 10- to 11-month-old mice which had normal cLP was not significantly different from young control mice, it is possible that luteal degeneration may be the principal cause of the earliest observable decrease in implantation rate. There is some indication that luteal function may be compromised in the late pre-menopausal human female (Collett, Wertenberger \& Fiske, 1954). These workers found that, in such women, the elevated basal body temperature associated with progesterone secretion frequently decreased prematurely.

Discussion has favoured the interpretation that decline in the rate of implantation in ageing mice was due to luteal failure. However, the possibility must be considered that the change noted in the CLP of ageing mice on the 8th day of pregnancy might have been caused by inadequate gonadotrophin support from the placenta. Such an interpretation seems unlikely since cL on the 8th day of pseudopregnancy, when no placentae are present, do not show similar changes (Harman \& Talbert, unpublished data).

It seems appropriate to speculate at this point whether the presence of degenerate CLP and the absence of recognizable CLP are two discrete events, or whether they are part of a continuum in which cLP fail at an increasingly early stage as the animals become older. A datum which would tend to support the latter view is the finding by Finn (1963) that pregnancy failed earlier in gestation with increasing maternal age.

There was also a trend in the older animals towards decline in efficiency of implantation in animals with GLP of normal appearance. This may indicate that intrinsic changes in the uterus can affect implantation efficiency, at least in older animals. Evidence of age-related failure of uterine function was found in mice by Finn (1966) and by Shapiro \& Talbert (1969). These workers found that the uteri of aged mice demonstrated a decrease in magnitude of the decidual response in both intact, pseudopregnant animals and in spayed females given exogenous progesterone and oestrogen. Similar findings have been reported in the hamster by Blaha (1967).

If there is, indeed, a failure of the ovary to support the process of implantation in ageing animals, the next logical step would be to determine whether 
this is caused by failure of the aged ovary to respond maximally to gonadotrophins, as demonstrated by Ortiz (1955) and by Green (1957), or by a decline with age in the level of gonadotrophic support of luteal function.

\section{ACKNOWLEDGMENTS}

This paper is based upon a portion of a thesis submitted by the senior author in partial fulfilment of the requirements for the degree of Doctor of Philosophy in Anatomy at the Downstate Medical Center, State University of New York.

The senior investigator in this study was a predoctoral fellow supported by a National Institutes of Health Training Grant (GM-379). This work was also supported by National Institute of Health Grant HD-02014.

The authors wish to thank Mr Ervin Wilson and Mr William Wade for their careful technical help in conducting this research.

\section{REFERENCES}

Asdell, S. A., Bogart, R. \& Sperling, G. (1941) The influence of age and rate of breeding upon the ability of the female rat to reproduce and raise young. Mem. Cornell Univ. agric Exp. Stn, No. 238.

BAssetT, D. L. (1943) The changes in the vascular pattern of the ovary of the rat during the estrous cycle. Am. F. Anat. 73, 251.

Biggers, J. D., Finn, C. A. \& MaLaren, A. (1962a) Long-term reproductive performance of female mice. I. Effect of removing one ovary. 7. Reprod. Fert. 3, 303.

Btggers, J. D., Finn, C. A. \& McLaren, A. (1962b) Long-term reproductive performance of female mice. II. Variation of litter size with parity. F. Reprod. Fert. 3, 313.

BLAHA, G. (1967) Effects of age, treatment, and method of induction on deciduomata in the golden hamster. Fert. Steril. 18, 477.

Collett, M. E., Wertenderger, G. E. \& Fiske, V. M. (1954) The effect of age upon the pattern of the menstrual cycle. Fert. Steril. 5, 437.

DeanesLy, R. (1930) The corpora lutea of the mouse with special reference to fat accumulation during the oestrous cycle. Proc. R. Soc. B, 106, 578.

Fins, C. A. (1963) Reproductive capacity and litter size in mice: effect of age and environment. J. Reprod. Fert. 6, 205.

Fins, C. A. (1966) The initiation of the decidual cell reaction in the uterus of the aged mouse. F. Reprod. Fert. 11, 423.

GrREN, J. A. (1957) Some effects of advancing age on the histology and reactivity of the mouse ovary. Anat. Rec. 129, 333.

Hollander, W. F. \& Strong, L. C. (1950) Intra-uterine mortality and placental fusions in the mouse. 7. exp. Zool. 115, 131.

JONEs, E. C. \& KROHN, P. L. (1959) Influence of the anterior pituitary on the aging process in the ovary. Nature, Lond. 183, 1155.

Jones, E. C. \& KROHN, P. L. (1961) Relationships between age, numbers of oocytes and fertility in virgin and multiparous mice of several strains. F. Endocr. 21, 469.

LOEB, L. (1948) Aging processes in the ovaries of mice belonging to strains differing in the incidence of mammary carcinoma. Archs Path. 46, 401.

ORTIZ, E. (1955) The relation of advancing age to reactivity of the reproductive system in the female hamster. Anat. Rec. 122, 517.

Shapiro, M. \& Talbert, G. B. (1969) Effect of maternal age upon decidualization. Anat. Rec. 163, 261.

Soderwalt, A. L., Kent, H. A., Turbyfill, C. L. \& Britenbaker, A. L. (1960) Variation in gestation length and litter size of the golden hamster, Mesocricetus auratus. F. Geront. 15, 246.

TALBert, G. B. \& KROHN, P. L. (1966) Effect of maternal age on viability of ova and uterine support of pregnancy in mice. $\mathcal{F}$. Reprod. Fert. 11, 399.

Thung, P.J., Bоoт, L. M. \& MunLBock, O. (1956) Senile changes in the oestrous cycle and in ovarian structure in some inbred strains of mice. Acta endocr., Copenh. 23, 8. 